\title{
Predictive value of XPG rs2296147T>C polymorphism on clinical outcomes of cancer patients
}

\author{
Yuhan Wang ${ }^{1}$, Yingying Han ${ }^{1}$, Qiang Weng ${ }^{1}$, Zhengrong Yuan ${ }^{1}$ \\ ${ }^{1}$ College of Biological Sciences and Technology, Beijing Forestry University, Beijing 100083, People's Republic of China \\ Correspondence to: Zhengrong Yuan, email: zryuan@bjfu.edu.cn \\ Keywords: XPG, rs2296147, cancer, clinical outcomes, meta-analysis \\ Received: May 24, $2016 \quad$ Accepted: August 11, $2016 \quad$ Published: August 29, 2016
}

\section{ABSTRACT}

The Xeroderma pigmentosum complementation group G (XPG) rs2296147T>C polymorphism is suspected to associate with the clinical outcomes of cancer patients. However, the results are inconsistent. This meta-analysis aimed to evaluate the reliable predictive value of XPG rs2296147T >C polymorphism on clinical outcomes of cancer patients. A total of $\mathbf{1 1}$ eligible studies were enrolled in this meta-analysis. Our results indicated that the cancer patients with TT and CT genotypes were significantly associated with better respond rates when compared with the CC genotype (TT versus (vs.) CC: odds ratio $(O R)=2.05,95 \%$ confidence intervals $(C I s), 1.32-3.20, P=$ 0.002 ; TT+CT vs. CC: $O R=1.57,95 \% C I, 1.14-2.17, P=0.005)$. The TT genotype and/or $\mathrm{T}$ allele might be associated with higher survival time for cancer patients than the CC genotype and/or C allele. The cumulative meta-analyses showed an apparent beneficial objective response of TT genotype on cancer patients. In conclusion, this meta-analysis suggests that the XPG rs2296147T $>C$ polymorphism is associated with the clinical outcomes of cancer patients. The XPG rs2296147T $>C$ polymorphism might be a predictive factor of prognosis in cancers patients and contribute to individual treatment in the future.

\section{INTRODUCTION}

Nowadays, cancer has emerged as one of the most serious public health problems worldwide [1-3]. Despite intensive efforts have been made to improve the efficacy of cancer diagnosis and therapy, the overall survival (OS) time of cancer patients is still short [1-3]. It is very necessary to identify more reliable biomarkers for early diagnosis, accurate prognosis prediction, and efficacy for cancer patients [2]. Emerging evidence has demonstrated that genetic factors are considered to influence the cancer development, treatment effectiveness, survival time of cancer patients, therefore affect the prognosis of patients $[3,4]$. It has been speculated that DNA damage was significantly associated with the DNA repair capacity [5-7]. The genetic variants in DNA repair genes alter the activity of DNA repair, thus influence the effectiveness of therapy, prognosis and survival of patients $[1,3,4,6]$. The DNA repair genes have been identified in different DNA repair pathways [5-7]. The nucleotide excision repair (NER) pathway is the most versatile repair mechanism responsible for repairing bulky DNA damage [5]. The xeroderma pigmentosum complementation group $\mathrm{G}(X P G)$, also known as excision repair cross-complementation group 5(ERCC5), is one of the critical DNA repair enzymes of NER pathway. $X P G$ gene is located on chromosome 13q32-q33, and encodes a protein of 1186 amino acids, which containing 15 exons and 14 introns. Previous studies indicate that the $X P G$ rs2296147T $>$ C polymorphism is suspected to have relationship with the clinical outcomes of cancer patients, such as colorectal cancer (CRC) [8-11], epithelial ovarian cancer (EOC) $[12,13]$, head and neck cancer(HNC) [14], non-small cell lung cancer (NSCLC) [15-19], gastric cancer (GC) [20] and osteosarcoma (OC) [21, 22]. Published data from these studies have shown inconsistent results. However, a systematic review and meta-analysis is still lacking. Thus, the aim of this meta-analysis was designed to summarize the currently available published findings and comprehensively assess the reliable predictive value of $X P G$ rs $2296147 \mathrm{~T}>\mathrm{C}$ polymorphism on clinical outcomes of cancer patients. 


\section{RESULTS}

\section{Studies characteristics}

Our initial systematic search retrieved 139 publications using different combinations of key terms. Based on our inclusion and exclusion criteria, eleven eligible publications were ultimately enrolled for the data pool in this meta-analysis [8, 9, 11, 13-19, 22] (Figure 1), altogether 5316 cancer patients. The general characteristics of enrolled studies are summarized in Table 1. These studies included five NSCLC studies, three CRC studies, one EOC study, one HNC study, and one OC study (Table 1). Ten studies were conducted on Asian patients, and one was conducted on Caucasian patients (Table 1). Eight studies were published in English and three studies were published in Chinese. Of these studies, five studies reported the objective response rate (ORR), eight studies reported the OS and hazard ratios (HRs), and seven studies reported the median progressionfree survival (PFS) and HRs (Table 2). The sample sizes of included studies ranged from 105 to 1901 cancer patients. Several genotyping methods were used in the enrolled studies, including the polymerase chain reaction (PCR)ligase detection reaction (PCR-LDR), PCR-restriction fragment length polymorphism (PCR-RFLP), Taqman realtime-PCR (Taqman RT-PCR), and Illumina GoldenGate assay with Sentrix Array Matrix and 96-well standard microtiter plates (Table 1).

\section{Objective response of $X P G$ rs2296147T $>C$ polymorphism}

A total of five eligible studies, including 1232 cancer patients, were qualified for the final analysis for objective response of XPG $\mathrm{rs} 2296147 \mathrm{~T}>\mathrm{C}$ polymorphism. We observed significant associations between objective response and $X P G$ rs2296147T $>C$ polymorphism (TT versus (vs.) $\mathrm{CC}$ : odds ratio (OR) $=2.05,95 \%$ confidence intervals (CIs), 1.32-3.20, $\mathrm{P}=$ 0.002, Figure 2A; TT+CT vs. CC: OR $=1.57,95 \% \mathrm{CI}$, $1.14-2.17, \mathrm{P}=0.005$, Table 3 ). However, there were no significant associations under other genetic models (CT vs. $\mathrm{CC}: \mathrm{OR}=1.38,95 \% \mathrm{CI}, 0.97-1.97, \mathrm{P}=0.078$; TT vs. $\mathrm{CT}+\mathrm{CC}$ : $\mathrm{OR}=1.26,95 \% \mathrm{CI}, 0.82-1.95, \mathrm{P}=0.302$, Figure 2B; T vs. C: $\mathrm{OR}=1.46,95 \% \mathrm{CI}, 0.99-2.17, \mathrm{P}=$ 0.058 , Table 3 ). In the stratified analyses by cancer type, an evidently increased risk was found in the OC (TT vs. $\mathrm{CC}: \mathrm{OR}=4.18,95 \%$ CIs, 1.74-10.04, $\mathrm{P}=0.001$, Figure $2 \mathrm{~A}$; TT+CT vs. CC: $\mathrm{OR}=2.66,95 \% \mathrm{CI}, 1.45-4.88, \mathrm{P}=$ 0.002; TT vs. $\mathrm{CT}+\mathrm{CC}: \mathrm{OR}=3.34,95 \% \mathrm{CI}, 1.43-7.79, \mathrm{P}$ $=0.005$, Figure 2B; T vs. $\mathrm{C}: \mathrm{OR}=2.64,95 \% \mathrm{CI}, 1.65-$ $4.21, \mathrm{P}<0.001$, Table 3 ). The cancer patients bearing the favorable T allele, TT and CT genotypes were associated

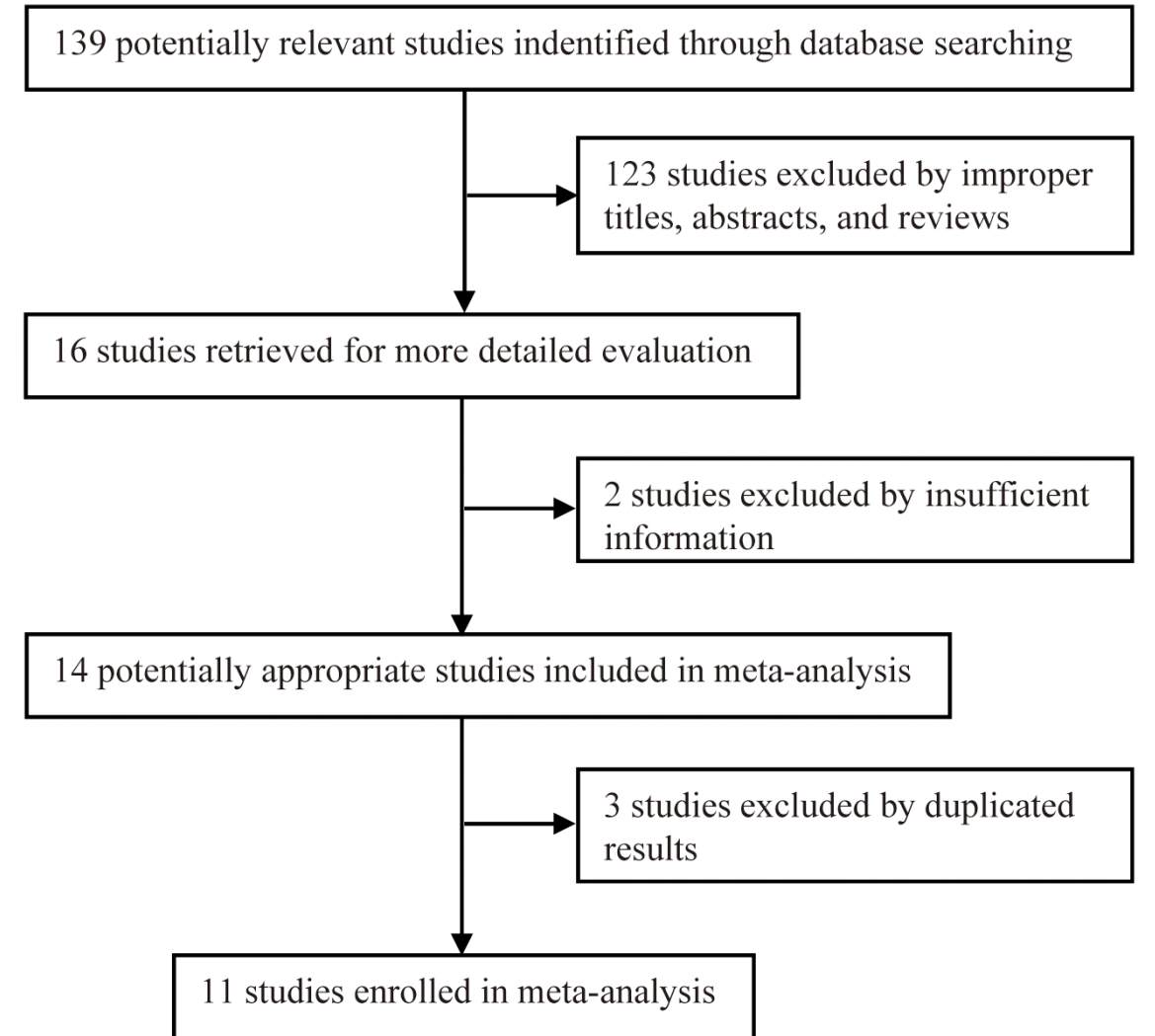

Figure 1: The flow diagram of the study selection process in meta-analysis. 
Table 1: The characteristics of enrolled studies in the meta-analysis

\begin{tabular}{|c|c|c|c|c|c|c|c|c|c|c|c|c|c|}
\hline \multirow[t]{2}{*}{ Study } & \multirow[t]{2}{*}{ Year } & \multirow[t]{2}{*}{ Country } & \multirow[t]{2}{*}{ Ethnicity } & \multirow{2}{*}{$\begin{array}{l}\text { Cancer } \\
\text { type }\end{array}$} & \multirow{2}{*}{$\begin{array}{c}\begin{array}{c}\text { Number } \\
\text { of } \\
\text { patients }\end{array} \\
\text { pats }\end{array}$} & \multirow{2}{*}{$\begin{array}{l}\text { Median age } \\
\quad \text { (year) }\end{array}$} & \multirow{2}{*}{$\begin{array}{l}\text { Clinical } \\
\text { stage }\end{array}$} & \multirow{2}{*}{$\begin{array}{l}\text { Evaluation } \\
\text { criterion }\end{array}$} & \multirow{2}{*}{$\begin{array}{c}\text { Clinical } \\
\text { outcomes }\end{array}$} & \multirow{2}{*}{$\begin{array}{l}\text { Genotyping } \\
\text { methods }\end{array}$} & \multicolumn{3}{|c|}{ Genotype distribution } \\
\hline & & & & & & & & & & & TT & $\mathrm{CT}$ & $\mathrm{CC}$ \\
\hline $\begin{array}{l}\text { Chen } \\
\text { et al., }\end{array}$ & 2009 & China & Asian & $\mathrm{CRC}$ & 105 & $\begin{array}{c}55 \\
(29-84)\end{array}$ & Advanced & RECIST & ORR/TTP & PCR-LDR & $27 / 42^{\mathrm{a}}$ & $12 / 18^{a}$ & $2 / 4^{a}$ \\
\hline $\begin{array}{l}\text { Chen } \\
\text { et al., }\end{array}$ & 2011 & China & Asian & $\mathrm{CRC}$ & 105 & $\begin{array}{c}55 \\
(29-84)\end{array}$ & Advanced & RECIST & PFS & PCR-LDR & - & - & - \\
\hline $\begin{array}{l}\text { He et } \\
\text { al., }\end{array}$ & 2013 & China & Asian & NSCLC & 228 & $\begin{array}{c}60 \\
(19-84)\end{array}$ & III-IV & WHO & ORR & PCR-RFLP & $61 / 85^{\mathrm{a}}$ & $28 / 44^{a}$ & $2 / 7^{\mathrm{a}}$ \\
\hline $\begin{array}{l}\text { Bai et } \\
\text { al., }\end{array}$ & 2013 & China & Asian & $\mathrm{OC}$ & 185 & $\begin{array}{c}16.8 \\
(6-39)\end{array}$ & NR & NR & ORR/OS & $\begin{array}{l}\text { Sequenome } \\
\text { MassARRAY } \\
\text { platform }\end{array}$ & $29 / 8^{a}$ & $31 / 18^{\mathrm{a}}$ & $46 / 53^{a}$ \\
\hline $\begin{array}{l}\text { Zhang } \\
\text { et al., }\end{array}$ & 2013 & China & Asian & NSCLC & 475 & $\begin{array}{c}64.3 \\
(31.7-76.1)\end{array}$ & IIIA/B-IV & $\begin{array}{c}\text { European } \\
\text { Organization } \\
\text { for Research } \\
\text { and Treatment } \\
\text { of Cancer }\end{array}$ & $\begin{array}{c}\text { ORR/OS/ } \\
\text { PFS }\end{array}$ & $\begin{array}{c}\text { Taqman RT- } \\
\text { PCR }\end{array}$ & $21 / 37^{a}$ & $45 / 99^{\mathrm{a}}$ & $71 / 178^{\mathrm{a}}$ \\
\hline $\begin{array}{l}\text { Yi et } \\
\text { al., }\end{array}$ & 2013 & China & Asian & NSCLC & 433 & $\begin{array}{c}61.4 \\
(32.5-78.7)\end{array}$ & IIIA/B-IV & NR & OS/PFS & $\begin{array}{l}\text { Taqman RT- } \\
\text { PCR }\end{array}$ & - & - & - \\
\hline $\begin{array}{l}\text { Hu et } \\
\text { al., }\end{array}$ & 2014 & China & Asian & NSCLC & 277 & $\begin{array}{c}63.1 \\
(28.7-74.5)\end{array}$ & IIIA/B-IV & WHO & OS/PFS & PCR-RFLP & - & - & - \\
\hline $\begin{array}{l}\text { Wyss } \\
\text { et al., }\end{array}$ & 2014 & USA & Caucasian & $\mathrm{HNC}$ & 1227 & NR & I-IV & NR & OS/OD/DSS & $\begin{array}{l}\text { Illumina } \\
\text { GoldenGate } \\
\text { assay with } \\
\text { Sentrix Array } \\
\text { Matrix and } \\
\text { 96-well } \\
\text { standard } \\
\text { microtiter } \\
\text { plates }\end{array}$ & - & - & - \\
\hline $\begin{array}{l}\text { Zou et } \\
\text { al., }\end{array}$ & 2015 & China & Asian & NSCLC & 246 & $\begin{array}{c}64.3 \\
(31.7-76.1)\end{array}$ & IIIA/B-IV & WHO & OS/PFS & PCR-RFLP & - & - & - \\
\hline $\begin{array}{l}\text { Hu et } \\
\text { al., }\end{array}$ & 2015 & China & Asian & $\mathrm{EOC}$ & 239 & NR & I-IV & NR & $\begin{array}{c}\text { ORR/OS/ } \\
\text { PFS }\end{array}$ & PCR-LDR & $90 / 51^{a}$ & $69 / 29^{a, b}$ & - \\
\hline $\begin{array}{l}\text { Wang } \\
\text { et al., }\end{array}$ & 2016 & China & Asian & $\mathrm{CRC}$ & 1901 & $\begin{array}{c}57.1 \\
(13-91)\end{array}$ & NR & NR & OS/PFS & $\begin{array}{c}\text { Taqman RT- } \\
\text { PCR }\end{array}$ & - & - & - \\
\hline
\end{tabular}

Abbreviations: CRC, colorectal cancer; DDS, disease-specific survival; EOC, epithelial ovarian cancer; HNC, Head and neck cancer; MST, median survival time; NR, not reported; NSCLC, non-small cell lung cancer; OC, osteosarcoma; OD, overall deaths; ORR, objective response rate; OS, overall survival; PCR-LDR, polymerase chain reaction (PCR)-ligase detection reaction; PCR-RFLP, PCR-restriction fragment length polymorphism; PFS, progression-free survival; RECIST, Response Evaluation Criteria in Solid Tumors; Taqman RT-PCR, Taqman real-time-PCR; TTP, time to progression (months); WHO, World Health Organization.

${ }^{a}$ Number of patients for ORR; in front of oblique line is good responder (complete response (CR) + partial response (PR)) and behind oblique line is poor responder (stable disease (SD) + progressive disease (PD)). ${ }^{b}$ Number of patients for CT and TT genotypes.

with better respond rates compared to those with the unfavorable $\mathrm{C}$ allele and $\mathrm{CC}$ genotype (Table 3).

\section{Overall survival of $X P G$ rs2296147T $>C$ polymorphism}

There were eight eligible studies with 4983 cancer patients, qualified for the final analysis of the relationship between the OS of cancer patients and $X P G$ rs2296147T $>$ C polymorphism. We detected a significant association between the OS of cancer patients and $X P G$
rs2296147T $>$ C polymorphism under $\mathrm{T}$ vs. $\mathrm{C}$ genetic model $(\mathrm{HR}=0.50,95 \% \mathrm{CI}, 0.38-0.66, \mathrm{P}<0.001$, Table $3)$. The stratified analyses by cancer type showed that the $X P G$ rs $2296147 \mathrm{~T}>\mathrm{C}$ polymorphism was statistically significantly associated with the OS of cancer patients in NSCLC (TT vs. CC, HR $=0.44,95 \%$ CI, 0.29-0.66, $\mathrm{P}<0.001$, Figure $3 \mathrm{~A}$; $\mathrm{TT}+\mathrm{CT}$ vs. $\mathrm{CC}: \mathrm{HR}=0.66,95 \%$ CI, 0.46-0.95, $\mathrm{P}=0.024$, Table 3). We also observed a significant association between the OS of EOC and $X P G$ rs2296147T $>\mathrm{C}$ polymorphism under $\mathrm{CC}+\mathrm{CT}$ vs. TT genetic model $(\mathrm{HR}=0.50,95 \% \mathrm{CI}, 0.28-0.88, \mathrm{P}=0.017$, 
Table 2: Association between $X P G$ rs2296147T $>$ C polymorphism and overall survival and progression-free survival

\begin{tabular}{|c|c|c|c|c|c|c|c|c|}
\hline Study & Year & HR & TT & CT & $\mathrm{CC}$ & $\mathbf{T T}+\mathbf{C T}$ & $\mathrm{CT}+\mathrm{CC}$ & $\mathbf{T}$ \\
\hline \multirow[t]{2}{*}{ Chen et al., } & 2011 & OS & - & - & - & - & - & - \\
\hline & & PFS & $1.23(0.73-2.07)$ & - & - & - & 1(Reference) & - \\
\hline \multirow[t]{2}{*}{ Bai et al., } & 2013 & OS & $0.47(0.17-0.94)$ & $1.36(0.64-2.85)$ & 1(Reference) & $0.84(0.58-1.55)$ & - & - \\
\hline & & PFS & - & - & - & - & - & - \\
\hline \multirow[t]{2}{*}{ Zhang et al., } & 2013 & OS & $0.50(0.27-0.95)$ & $0.72(0.46-1.16)$ & 1(Reference) & - & - & - \\
\hline & & PFS & $0.75(0.38-1.55)$ & $0.90(0.55-1.50)$ & 1(Reference) & - & - & - \\
\hline \multirow[t]{2}{*}{ Yi et al., } & 2013 & OS & - & - & 1(Reference) & $0.66(0.48-0.99)$ & - & - \\
\hline & & PFS & - & - & 1(Reference) & $0.73(0.51-0.97)$ & - & - \\
\hline \multirow[t]{2}{*}{ Hu et al., } & 2014 & OS & $0.47(0.22-0.93)$ & $0.79(0.51-1.23)$ & 1(Reference) & - & - & $0.49(0.36-0.68)^{a}$ \\
\hline & & PFS & $0.48(0.24-0.93)$ & $0.85(0.56-1.29)$ & 1(Reference) & - & - & $0.52(0.38-0.70)^{\mathrm{a}}$ \\
\hline \multirow[t]{4}{*}{ Wyss et al., } & 2014 & OS & 1(Reference) & - & - & - & $0.78(0.62-0.97)^{b}$ & - \\
\hline & & PFS & - & - & - & - & - & - \\
\hline & & OS & 1(Reference) & - & - & - & $1.07(0.77-1.48)^{\mathrm{c}}$ & - \\
\hline & & PFS & - & - & - & - & - & \\
\hline \multirow[t]{2}{*}{ Zou et al., } & 2015 & OS & $0.32(0.14-0.71)$ & $0.89(0.46-1.76)$ & 1(Reference) & - & - & $0.54(0.32-0.98)^{\mathrm{a}}$ \\
\hline & & PFS & $0.31(0.13-0.73)$ & $0.55(0.27-1.12)$ & 1(Reference) & - & - & $0.44(0.24-0.83)^{\mathrm{a}}$ \\
\hline \multirow[t]{2}{*}{ Hu et al., } & 2015 & OS & 1(Reference) & - & - & - & $0.50(0.28-0.87)$ & - \\
\hline & & PFS & 1(Reference) & - & - & - & $0.63(0.41-0.98)$ & - \\
\hline \multirow[t]{2}{*}{ Wang et al., } & 2016 & OS & $1.49(0.92-2.43)$ & $1.38(0.84-2.28)$ & 1(Reference) & $1.21(0.95-1.54)$ & - & - \\
\hline & & PFS & $1.74(1.08-2.80)$ & $1.78(1.09-2.90)$ & 1(Reference) & $1.32(1.05-1.67)$ & - & - \\
\hline
\end{tabular}

Abbreviations: HR: hazard ratio; OS, overall survival; PFS, progression-free survival.

${ }^{\mathrm{a}} \mathrm{HR}$ for T versus C. ${ }^{\mathrm{b}} \mathrm{HR}$ for Whites. ${ }^{\mathrm{c}} \mathrm{HR}$ for African Americans.

Table 3). Our results indicated that the TT genotype and/ or $\mathrm{T}$ allele might be associated with higher survival time for cancer patients than the CC genotype and/or C allele (Table 3).

\section{Progression-free survival of $X P G$ rs2296147T $>C$ polymorphism}

Seven studies with a total number of 3676 cancer patients were recruited for the final analysis of the relationship between the PFS of cancer patients and $X P G$ rs 2296147T $>$ C polymorphism. The $X P G$ rs $2296147 \mathrm{~T}>\mathrm{C}$ polymorphism was significantly associated with the PFS of cancer patients $(\mathrm{CC}+\mathrm{CT}$ vs. TT, $\mathrm{HR}=0.70,95 \% \mathrm{CI}$, $0.50-0.98, \mathrm{P}=0.035$; T vs. $\mathrm{C}, \mathrm{HR}=0.50,95 \% \mathrm{CI}, 0.38$ $0.66, \mathrm{P}<0.001$, Table 3 ). When stratified by cancer type, a significant association between the $X P G$ rs $2296147 \mathrm{~T}>\mathrm{C}$ polymorphism and PFS of NSCLC patients was found under TT vs. $\mathrm{CC}$ genetic model $(\mathrm{HR}=0.50,95 \% \mathrm{CI}$, $0.31-0.81, \mathrm{P}=0.005$, Figure $3 \mathrm{~B}$, Table 3 ). There was a significant association between the $X P G$ rs $2296147 \mathrm{~T}>\mathrm{C}$ polymorphism and $\mathrm{PFS}$ of EOC patients under $\mathrm{CC}+\mathrm{CT}$ vs. TT genetic model $(\mathrm{HR}=0.63,95 \% \mathrm{CI}, 0.41-0.97, \mathrm{P}=$
0.038 , Table 3). We also detected significant associations between the $X P G$ rs $2296147 \mathrm{~T}>\mathrm{C}$ polymorphism and $\mathrm{PFS}$ of CRC patients (TT vs. CC, HR $=1.74,95 \% \mathrm{CI}, 1.08$ 2.82, $\mathrm{P}=0.023$, Figure 3B; $\mathrm{CT}$ vs. $\mathrm{CC}, \mathrm{HR}=1.78,95 \%$ CI, $1.09-2.90, \mathrm{P}=0.021$; $\mathrm{TT}+\mathrm{CT}$ vs. $\mathrm{CC}, \mathrm{HR}=1.32,95 \%$ CI, 1.05-1.67, P = 0.019, Table 3).

No other significant associations between the $X P G$ rs 2296147T $>C$ polymorphism and clinical outcomes of cancer patients were observed in this meta-analysis (Table 3).

\section{Publication bias and sensitivity analysis}

No obvious publication bias was found through either the inverted funnel plots or Begg's test (data not shown). In the sensitivity analysis, changing the effect models had no significant effects on the pooled ORs/HRs, and did not influence the final strength of association between $X P G$ rs2296147T $>C$ polymorphism and clinical outcomes of cancer patients. The influence of excluding each study on the pooled ORs/HRs was recalculated by repeating the metaanalysis, and the results indicated that excluding each study did not significantly change the overall effects, suggesting that our results are credible. 


\section{Cumulative meta-analyses}

The cumulative meta-analyses based on year of publication showed an apparent beneficial objective response of TT genotype on cancer patients in the recent studies. As shown in Figure 4, between 2009 and 2014, five studies were enrolled, resulting in an overall effect estimate of OR being 1.26 (95\% CI, 0.82-1.95, TT vs. $\mathrm{CT}+\mathrm{CC}$, Figure 4).

\section{DISCUSSION}

The NER is one of the major pathways of the DNA repair system, and the $X P G$ gene is an indispensable component of the NER system. Many of SNPs in $X P G$ gene have been reported to be associated with the outcomes of various cancers [5, 8-29]. The association between $X P G$ rs2296147T $>C$ polymorphism and clinical outcomes of cancer patients has been widely studied $[8$, 9, 11, 13-19, 22]. Bai et al observed that OC patients with $X P G$ rs2296147T $>C$ TT genotype were associated with better response to chemotherapy and longer OS than CC genotype (OR (95\% CI) for ORR: 4.17 (1.6411.54); HR (95\% CI) for OS: 0.47 (0.17-0.94)) [22]. The $X P G$ polymorphisms could be used as predictive markers for prognosis of OC [22]. Zhang et al found a significant decreased risk of death from NSCLC among patients carrying the $X P G$ rs2296147T $>C$ TT genotype when compared with the CC genotype (HR $(95 \% \mathrm{CI})$ for OS: $0.50(0.27-0.95))$ [18]. The $X P G$ rs $2296147 \mathrm{~T}>\mathrm{C}$ polymorphism is associated with response to platinumbased chemotherapy in advanced NSCLC, and could be predictive of prognosis [18]. Yi et al indicated that NSCLC patients carrying $X P G$ rs $2296147 \mathrm{~T}>\mathrm{C} \mathrm{TT}+\mathrm{CT}$ genotype
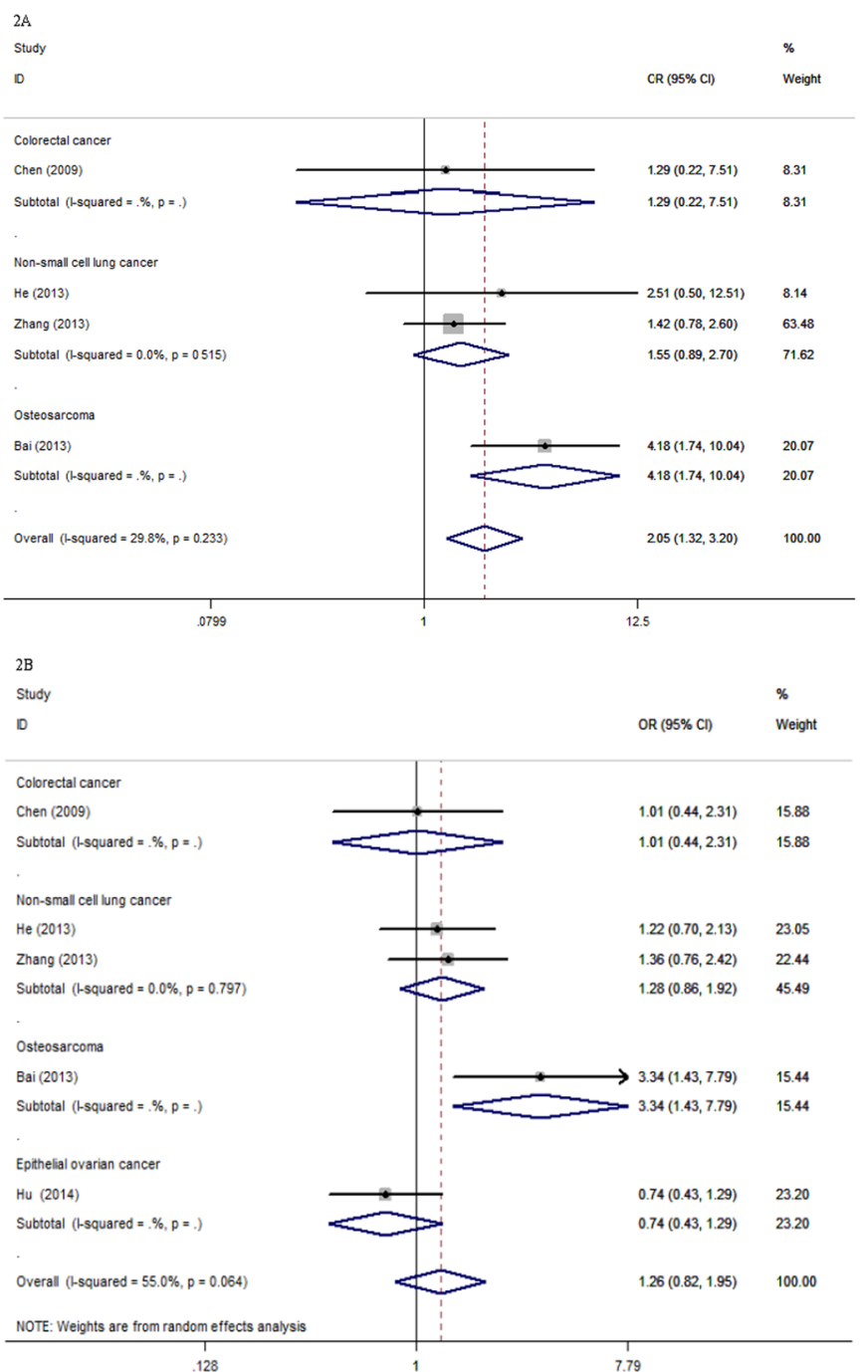

Figure 2: Forest plots for the association between $X P G$ rs2296147T $>C$ polymorphism and objective response rate of cancer patients. CI: confidence interval; ORR: objective response rate; ORs: odds ratios; vs.: versus. Figure $2 \mathrm{~A}$. ORR (ORs and $95 \% \mathrm{CI})$ under TT vs. CC in cancer type. Figure 2B. ORR (ORs and 95\% CI) under TT vs. CT+CC in cancer type. 
Table 3: Meta-analysis of the association between $X P G$ rs2296147T $>C$ polymorphism and objective response rate, overall survival and progression-free survival

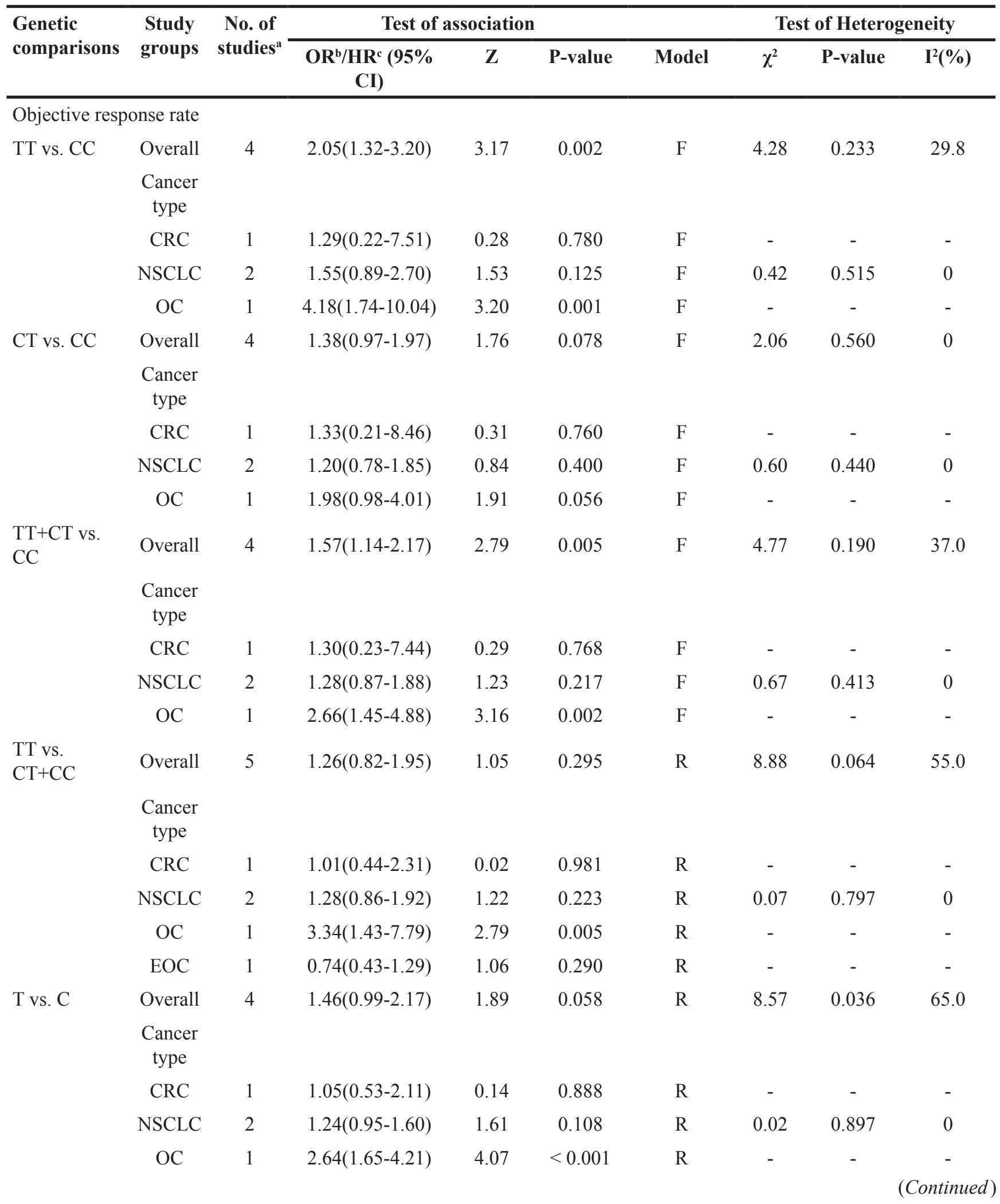




\begin{tabular}{|c|c|c|c|c|c|c|c|c|c|}
\hline \multirow{2}{*}{$\begin{array}{l}\text { Genetic } \\
\text { comparisons }\end{array}$} & \multirow{2}{*}{$\begin{array}{c}\text { Study } \\
\text { groups }\end{array}$} & \multirow{2}{*}{$\begin{array}{c}\text { No. of } \\
\text { studies }\end{array}$} & \multicolumn{3}{|c|}{ Test of association } & \multirow[b]{2}{*}{ Model } & \multicolumn{3}{|c|}{ Test of Heterogeneity } \\
\hline & & & $\begin{array}{c}\mathrm{OR}^{\mathrm{b}} / \mathrm{HR}^{\mathrm{c}}(95 \% \\
\mathrm{CI})\end{array}$ & $\mathbf{Z}$ & P-value & & $\chi^{2}$ & P-value & $I^{2}(\%)$ \\
\hline \multicolumn{10}{|c|}{ Overall survival } \\
\hline \multirow[t]{5}{*}{ TT vs. CC } & Overall & 5 & $0.58(0.32-1.07)$ & 1.75 & 0.080 & $\mathrm{R}$ & 16.00 & 0.003 & 75.00 \\
\hline & $\begin{array}{l}\text { Cancer } \\
\text { type }\end{array}$ & & & & & & & & \\
\hline & $\mathrm{OC}$ & 1 & $0.47(0.20-1.11)$ & 1.73 & 0.084 & $\mathrm{R}$ & - & - & - \\
\hline & NSCLC & 3 & $0.44(0.29-0.66)$ & 3.96 & $<0.001$ & $\mathrm{R}$ & 0.78 & 0.677 & 0 \\
\hline & CRC & 1 & $1.49(0.92-2.43)$ & 1.61 & 0.106 & $\mathrm{R}$ & - & - & - \\
\hline \multirow[t]{5}{*}{ CT vs. CC } & Overall & 5 & $0.94(0.74-1.19)$ & 0.54 & 0.588 & $\mathrm{~F}$ & 5.11 & 0.276 & 21.80 \\
\hline & $\begin{array}{l}\text { Cancer } \\
\text { type }\end{array}$ & & & & & & & & \\
\hline & $\mathrm{OC}$ & 1 & $1.36(0.64-2.87)$ & 0.81 & 0.420 & F & - & - & - \\
\hline & NSCLC & 3 & $0.78(0.58-1.04)$ & 1.70 & 0.089 & $\mathrm{~F}$ & 0.27 & 0.875 & 0 \\
\hline & $\mathrm{CRC}$ & 1 & $1.38(0.84-2.27)$ & 1.26 & 0.206 & $\mathrm{~F}$ & - & - & - \\
\hline \multirow[t]{5}{*}{$\begin{array}{l}\mathrm{TT}+\mathrm{CT} \text { vs. } \\
\mathrm{CC}\end{array}$} & Overall & 3 & $0.89(0.60-1.34)$ & 0.54 & 0.540 & $\mathrm{R}$ & 7.89 & 0.019 & 74.60 \\
\hline & $\begin{array}{l}\text { Cancer } \\
\text { type }\end{array}$ & & & & & & & & \\
\hline & $\mathrm{OC}$ & 1 & $0.84(0.51-1.37)$ & 0.70 & 0.487 & $\mathrm{R}$ & - & - & - \\
\hline & NSCLC & 1 & $0.66(0.46-0.95)$ & 2.25 & 0.024 & $\mathrm{R}$ & - & - & - \\
\hline & $\mathrm{CRC}$ & 1 & $1.21(0.95-1.54)$ & 1.55 & 0.122 & $\mathrm{R}$ & - & - & - \\
\hline T vs. C & Overall & 2 & $0.50(0.38-0.66)$ & 4.89 & $<0.001$ & $\mathrm{~F}$ & 0.09 & 0.767 & 0 \\
\hline \multirow[t]{4}{*}{$\begin{array}{l}\text { CC+CT vs. } \\
\text { TT }\end{array}$} & Overall & 3 & $0.79(0.57-1.11)$ & 1.34 & 0.180 & $\mathrm{R}$ & 5.67 & 0.059 & 64.70 \\
\hline & $\begin{array}{l}\text { Cancer } \\
\text { type }\end{array}$ & & & & & & & & \\
\hline & $\mathrm{HNC}$ & 2 & $0.89(0.66-1.21)$ & 0.73 & 0.467 & $\mathrm{R}$ & 2.45 & 0.118 & 59.20 \\
\hline & EOC & 1 & $0.50(0.28-0.88)$ & 2.40 & 0.017 & $\mathrm{R}$ & - & - & - \\
\hline \multicolumn{10}{|c|}{ Progression-free survival } \\
\hline \multirow[t]{4}{*}{ TT vs. CC } & Overall & 4 & $0.69(0.32-1.52)$ & 0.91 & 0.361 & $\mathrm{R}$ & 16.76 & 0.001 & 82.10 \\
\hline & $\begin{array}{l}\text { Cancer } \\
\text { type }\end{array}$ & & & & & & & & \\
\hline & NSCLC & 3 & $0.50(0.31-0.81)$ & 2.84 & 0.005 & $\mathrm{R}$ & 2.47 & 0.291 & 18.90 \\
\hline & CRC & 1 & $1.74(1.08-2.82)$ & 2.28 & 0.023 & $\mathrm{R}$ & - & - & - \\
\hline \multirow[t]{4}{*}{ CT vs. CC } & Overall & 4 & $0.96(0.62-1.50)$ & 0.17 & 0.866 & $\mathrm{R}$ & 8.80 & 0.032 & 65.90 \\
\hline & $\begin{array}{l}\text { Cancer } \\
\text { type }\end{array}$ & & & & & & & & \\
\hline & NSCLC & 3 & $0.81(0.60-1.08)$ & 1.45 & 0.146 & $\mathrm{R}$ & 1.36 & 0.507 & 0 \\
\hline & CRC & 1 & $1.78(1.09-2.90)$ & 2.31 & 0.021 & $\mathrm{R}$ & - & - & - \\
\hline
\end{tabular}




\begin{tabular}{|c|c|c|c|c|c|c|c|c|c|}
\hline \multirow{2}{*}{$\begin{array}{l}\text { Genetic } \\
\text { comparisons }\end{array}$} & \multirow{2}{*}{$\begin{array}{l}\text { Study } \\
\text { groups }\end{array}$} & \multirow{2}{*}{$\begin{array}{l}\text { No. of } \\
\text { studies }\end{array}$} & \multicolumn{3}{|c|}{ Test of association } & \multirow[b]{2}{*}{ Model } & \multicolumn{3}{|c|}{ Test of Heterogeneity } \\
\hline & & & $\begin{array}{c}\mathrm{OR}^{\mathrm{b}} / \mathrm{HR}^{\mathrm{c}}(95 \% \\
\text { CI })\end{array}$ & $\mathbf{Z}$ & P-value & & $\chi^{2}$ & P-value & $I^{2}(\%)$ \\
\hline \multirow{4}{*}{$\begin{array}{l}\mathrm{TT}+\mathrm{CT} \text { vs. } \\
\mathrm{CC}\end{array}$} & Overall & 2 & $0.99(0.56-1.77)$ & 0.03 & 0.979 & $\mathrm{R}$ & 8.58 & 0.003 & 88.30 \\
\hline & $\begin{array}{l}\text { Cancer } \\
\text { type }\end{array}$ & & & & & & & & \\
\hline & NSCLC & 1 & $0.73(0.53-1.01)$ & 1.92 & 0.055 & $\mathrm{R}$ & - & - & - \\
\hline & $\mathrm{CRC}$ & 1 & $1.32(1.05-1.67)$ & 2.35 & 0.019 & $\mathrm{R}$ & - & - & - \\
\hline T vs. C & Overall & 2 & $0.50(0.38-0.66)$ & 4.91 & $<0.001$ & $\mathrm{~F}$ & 0.22 & 0.636 & 0 \\
\hline \multirow[t]{4}{*}{$\begin{array}{l}\text { CC+CT vs. } \\
\text { TT }\end{array}$} & Overall & 2 & $0.70(0.50-0.98)$ & 2.10 & 0.035 & $\mathrm{~F}$ & 0.53 & 0.468 & 0 \\
\hline & $\begin{array}{l}\text { Cancer } \\
\text { type }\end{array}$ & & & & & & & & \\
\hline & $\mathrm{CRC}$ & 1 & $0.81(0.48-1.36)$ & 0.79 & 0.428 & $\mathrm{~F}$ & - & - & - \\
\hline & EOC & 1 & $0.63(0.41-0.97)$ & 2.08 & 0.038 & $\mathrm{~F}$ & - & - & - \\
\hline
\end{tabular}

Note: CI, confidence interval; CRC, colorectal cancer; EOC, epithelial ovarian cancer; HNC, Head and neck cancer; HR, hazard ratio; NSCLC, non-small cell lung cancer; OC, osteosarcoma; OR, odds ratio; vs., versus; F, fixed effect model; R, random effect model; Random effect model was chosen when P-value $<0.10$ and/or $\mathrm{I}^{2}>50 \%$ for heterogeneity test; otherwise fixed effect model was used.

${ }^{a}$ The detailed references are given in Table 1 and 2. ${ }^{\mathrm{b}}$ The OR for objective response rate. ${ }^{\mathrm{c}}$ The HR for overall survival and progression-free survival.

had a significantly longer median PFS and OS than CC genotype (HR (95\% CI) for PFS: 0.73(0.51-0.97); HR (95\% CI) for OS: $0.66(0.48-0.99))$. The $X P G$ rs 2296147 $\mathrm{T}>\mathrm{C} \mathrm{TT}+\mathrm{CT}$ genotype contribute to the better survival of NSCLC [19]. Hu et al reported that individuals carrying $X P G$ rs2296147T $>\mathrm{C}$ T allele was associated with better PFS and OS of NSCLC (HR (95\% CI) for PFS: 0.52 (0.38$0.70)$; HR (95\% CI) for OS: 0.49(0.36-0.68)) [16]. Zou et al indicated that patients carrying the $X P G$ rs $2296147 \mathrm{~T}>\mathrm{C}$ TT genotype had a significantly reduced risk of developing progressive disease or dying from NSCLC (HR $(95 \% \mathrm{CI})$ for PFS: $0.31(0.13-0.73)$; HR $(95 \% \mathrm{CI})$ for OS: 0.32 (0.14-0.71)) [15]. These studies suggest that the $X P G$ rs2296147T $>C$ polymorphism could be used as surrogate markers toward individualizing NSCLC treatment strategies [15, 16, 19]. However, He et al reported that there was no statistically significant association between $X P G$ rs2296147T $>C$ polymorphism and treatment response in NSCLC [17]. In addition, Chen et al suggested that no significant association was found between the $X P G$ rs2296147T $>$ C polymorphism and chemotherapy response in patients with advanced CRC $[9,10]$. Hu et al observed that the $X P G$ rs $2296147 \mathrm{~T}>\mathrm{C}$ C allele was associated with the PFS and OS of EOC compared with the TT genotype
(HR (95\% CI) for PFS: 0.63 (0.41 0.98); HR (95\% CI) for OS: 0.50 (0.28 0.87)) [12]. The $X P G$ rs2296147T $>C$ polymorphism may play as the marker in predicting the clinical outcomes of EOC treated with platinum chemotherapy [12]. Wang reported that CRC patients carrying the $X P G$ rs $2296147 \mathrm{~T}>\mathrm{C} \mathrm{TT}+\mathrm{CT}$ genotype had a significantly shorter median 10 years PFS than those carrying CC genotype $(\mathrm{HR}=1.324,95 \% \mathrm{CI}, 1.05-1.67)$ [8]. The $X P G$ rs $2296147 \mathrm{~T}>\mathrm{C}$ polymorphism could be predictive of unfavorable prognosis of CRC patients [8]. Results from these published studies remain conflicting rather than conclusive.

In the present study, we firstly conducted a systematic meta-analysis to assess the predictive value of XPG rs2296147T $>\mathrm{C}$ polymorphism on clinical outcomes of cancer patients. Results from this study could provide more reliable and precise comprehensive evaluation. Fortunately, we are delighted to find that the cancer patients carrying $X P G$ rs2296147T $>C$ T allele are associated with higher survival time and lower risks of death compared with those carrying $\mathrm{C}$ allele. Our cumulative meta-analysis indicated a distinct trend toward an apparent better respond rate for TT genotype of $X P G$ rs2296147T $>$ C polymorphism in cancer patients, which 


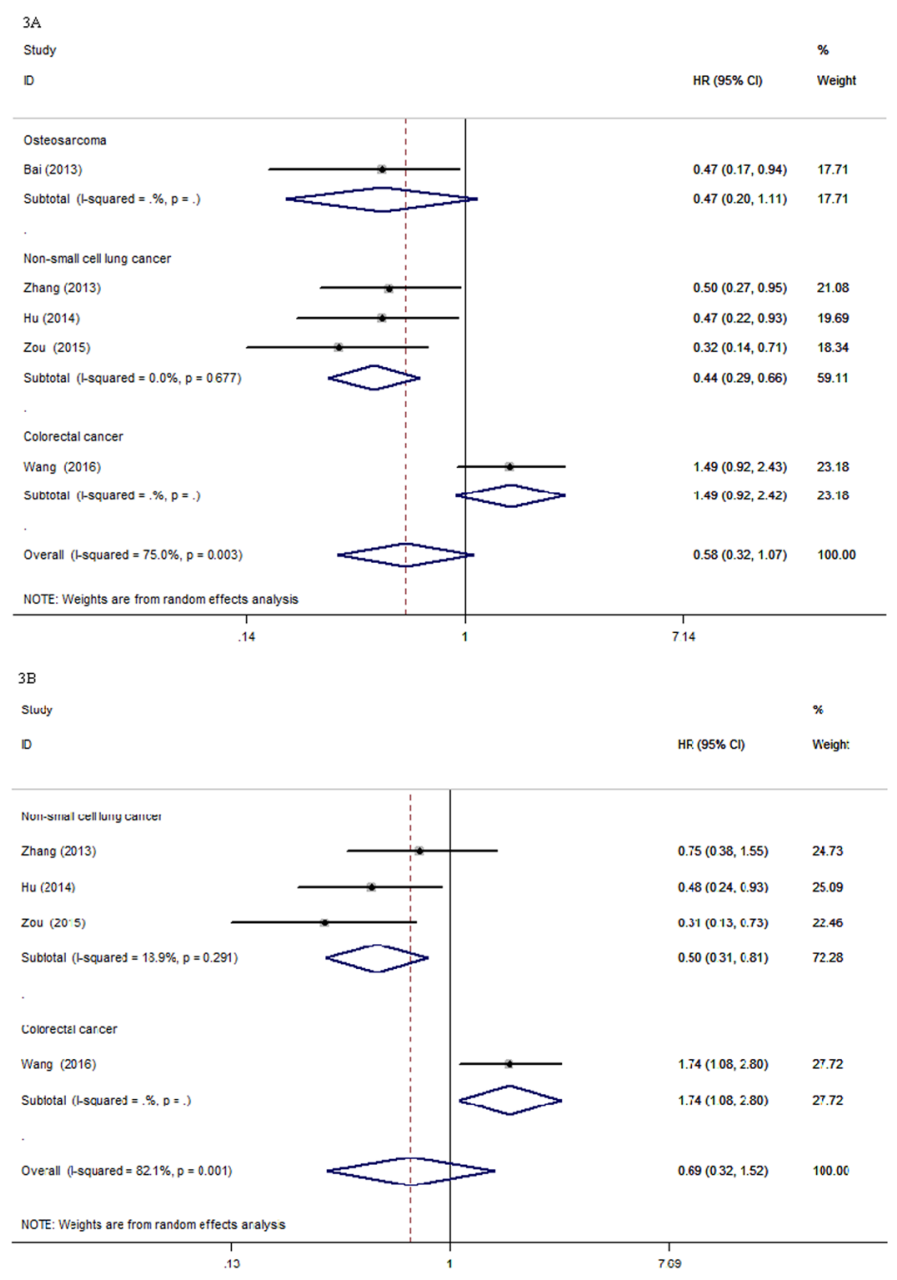

Figure 3: Forest plots for the association between $X P G$ rs2296147T $>C$ polymorphism and overall survival and progression-free survival of cancer patients. CI: confidence interval; HRs: Hazard ratios; OS: overall survival; PFS: progressionfree survival; vs.: versus. Figure 3A. OS (HRs and 95\% CI) under TT vs. CC in cancer type. Figure 3B. PFS (HRs and 95\% CI) under TT vs. CC in cancer type.

\section{Study}

ID

$\mathrm{OR}(95 \% \mathrm{Cl})$

\begin{tabular}{|c|c|}
\hline Chen (2009) & $1.01(0.44,2.31)$ \\
\hline $\mathrm{He}$ (2013) & $1.15(0.72,1.83)$ \\
\hline Bai (2013) & $1.55(0.80,3.01)$ \\
\hline Zhang (2013) & $1.47(0.95,2.27)$ \\
\hline $\mathrm{Hu}(2014)$ & $1.26(0.82,1.95)$ \\
\hline .333 & 01 \\
\hline
\end{tabular}

Figure 4: Forest plot for cumulative meta-analysis to sort out the time-tendency of clinical outcomes in cancer patients for XPG rs2296147T >C polymorphism. CI: confidence interval; ORR: objective response rate; ORs: odds ratios; vs.: versus. ORR (ORs and 95\% CI) under TT vs. CT+CC. 
also showed the stable time-dependent trend (Figure 4). The sequential year-to-year cumulative meta-analyses could have made the evidence much clearer earlier. It may help planning further clinical trials, preventing many redundant trials, redirecting trial design, and leading to sufficient assessment of clinical outcomes. Thus, findings from this cumulative meta-analysis about the response rates of $X P G$ rs2296147T $>C$ polymorphism in cancer patients should be weighed with caution. Our findings suggested that the $X P G$ rs $2296147 \mathrm{~T}>\mathrm{C}$ polymorphism could be a predictive factor for clinical outcomes of human cancers. The XPG rs2296147T $>$ C polymorphism might be used as a biomarker in personalized cancer treatment strategies.

Some potential limitations in this meta-analysis should be noted when interpreting our findings. Firstly, although the sample size of our study was relatively large by collecting all enrolled studies, the statistical power was still limited in the stratified analyses because of the relatively small sample sizes. Some of the findings in stratified analyses may have been undervalued, because only one trial was available for analyses. Many important confounding factors were not taken into account in the stratified analyses, such as age, gender, ethnicities, cancer pathology types, cancer stage, cancer history, smoking habit, specific anti-cancer drugs, treatment regimens and test methods. These factors could contribute to the clinical outcomes of cancer patients. However, few of included studies provided sufficient data for stratified analyses, thus making such stratified analyses impossible. Secondly, some significant heterogeneity between studies did observed. However, this heterogeneity was not significantly change the main conclusions, because our findings reflected the most current state of this issue in published studies. Our analyses were based on unadjusted estimates, since not all published studies calculating adjusted estimates. Thirdly, all of included studies were performed in Asians (Chinese), excepting one study in Caucasian populations (Whites and African Americans). Fourthly, only published studies in Chinese and English were included, published studies in other languages, ongoing studies and unpublished data were not obtained. These may have caused some biases in our estimates. Therefore, to make the result more accurate and reliable, further studies should avoid these pitfalls.

\section{CONCLUSIONS}

In conclusion, despite the limitations, this meta-analysis indicates that the $X P G$ rs $2296147 \mathrm{~T}>\mathrm{C}$ polymorphism is associated with the clinical outcomes of cancer patients. Our findings suggest a predictive role for $X P G$ rs2296147T $>\mathrm{C}$ polymorphism in clinical outcomes of cancer patients. The $X P G$ rs $2296147 \mathrm{~T}>\mathrm{C}$ polymorphism should be considered as a prognostic factor in human cancers. Further well-designed functional studies with large sample sizes in diverse ethnic populations will be necessary to validate these findings in the future.

\section{MATERIALS AND METHODS}

\section{Literature search strategies}

We systematically retrieved the relevant literatures using the following search terms " $X P G$ or Xeroderma pigmentosum complementation group G", "ERCC5 or Excision repair cross-complementation group 5", "rs2296147", "SNP or genetic polymorphism or variation", and "cancer or tumour or tumor or neoplasm or carcinoma" from the PubMed, ISI Web of Science, Excerpta Medica Database (EMBASE), Google Scholar, Wiley Online Library, ScienceDirect, Springer, VIP Database for Chinese Technical Periodicals, WANFANG Data, and Chinese National Knowledge Infrastructure (CNKI) databases (the last search was updated on May 20, 2016). We searched the articles without the restriction of country, race, languages and publication date. Reference lists were manually searched for further additionally relevant studies.

\section{Inclusion and exclusion criteria}

The inclusion criteria were as follows: (1). All patients diagnosed with cancer should be histologically confirmed; (2). XPG rs2296147T $>$ C polymorphism should be genotyped; (3). Treatments and clinical outcomes (i.e., ORR, OS, PFS) should be reported; (4). Sufficient data should be provided to estimate relative risks (i.e., ORs and HRs with corresponding to $95 \%$ CIs) for prognostic effects of cancer patients; (5). Only full-text articles were enrolled. The exclusion criteria were utilized to exclude the literatures: (1). Abstracts, letters, comments, reviews and meta-analysis; (2). Duplicated studies; (3). Not reported sufficient data; (4). The corresponding authors were not provided the relevant information upon our request.

\section{Data extraction}

Two investigators (Yuhan Wang and Zhengrong Yuan) independently extracted data from the included studies. The discrepancies between investigators were discussed and solved with consensus from our team's decision. The following information was extracted: the first author's name, year of publication, country, ethnicities, cancer type, number of patients, median age (year), clinical stage, evaluation criterion, clinical outcomes (ORR, OS, PFS, time to progression (TTP), overall deaths (OD), disease-specific survival (DSS), HRs with corresponding to $95 \% \mathrm{CIs}$ ), genotyping methods, and the number of responders and non-responders in different genotypes. 


\section{Statistical analysis}

We performed this meta-analysis according to the PRISMA guidelines (Figure S1 and Table S1) [30]. The ORR, OS, PFS, ORs, HRs with corresponding to $95 \%$ CIs were extracted from the included articles. The ORs and $95 \%$ CIs were calculated for the objective response vs. no response after treatment (complete response (CR) + partial response (PR) vs. progressive disease (PD) + stable disease (SD)). The HRs with corresponding to $95 \%$ CIs of OS and PFS were evaluated from the raw data of enrolled studies. We evaluated the association between $X P G$ rs2296147T $>$ C polymorphism and clinical outcomes of cancer patients by pooled ORs/HRs with corresponding to $95 \%$ CIs under different genetic models (TT vs. CC, $\mathrm{CT}$ vs. $\mathrm{CC}, \mathrm{TT}+\mathrm{CT}$ vs. $\mathrm{CC}, \mathrm{TT}$ vs. $\mathrm{CT}+\mathrm{CC}, \mathrm{T}$ vs. $\mathrm{C}$, $\mathrm{CC}+\mathrm{CT}$ vs. TT). Then, we conducted the stratification analyses by cancer type. The significance of pooled ORs/ HRs was assessed by the Z-test. The between-study heterogeneity was assessed with the Cochran's chi-squarebased Q-test [31, 32] and $\mathrm{I}^{2}$ index [33]. The P-value > 0.10 and/or $\mathrm{I}^{2}$ index $<50 \%$ indicates no significant heterogeneity between studies [34], so the pooled ORs/ HRs were evaluated using the fixed-effects model (the Mantel-Haenszel method) [35]. Otherwise, the randomeffects model with the DerSimonian and Laird method was utilized [36]. The potential publication bias was investigated by the inverted funnel plots and Begg's test [37]. The sensitivity analysis was examined by changing the effect models and excluding each study to recalculate the ORs/HRs and $95 \%$ CIs. To sort out the time-tendency of clinical outcomes of cancer patients, we conducted a sequential year-to-year cumulative meta-analyses. All statistical analyses were carried out with the STATA software version 11.0 (STATA Corporation, College Station, TX, USA). All P-values were two-sided test with a significant level of $\mathrm{P}<0.05$.

\section{ACKNOWLEDGMENTS}

The study was financially supported by the Student Research Training Program of Beijing Forestry University (NO. X201610022054), the Fundamental Research Funds for the Central Universities (NO. BLX2014-20, BLX2013024), the National Natural Science Foundation of China (NO. 31201768), and the Beijing Natural Science Foundation (NO. 8142029, 6133033).

\section{CONFLICTS OF INTEREST}

The authors declare that they have no competing interests.

\section{Authors' contributions}

Yuan ZR and Weng Q were involved in the conception and design of the study. Wang YH and Yuan ZR did the literature searches, data extraction, and analyses. Yuan ZR, Han YY and Weng Q assessed the data quality. Wang YH, Yuan ZR, Han YY and Weng Q contributed to data analysis and interpretation of the results. All authors reviewed and approved the final manuscript.

\section{REFERENCES}

1. Cao Z, Song J, Wang J, Guo X, Yu S, Dong W. Association between polymorphisms in XRCC1 gene and treatment outcomes of patients with advanced gastric cancer: a systematic review and meta-analysis. PLoS One. 2014; 9: e85357.

2. Zhang J, Zhang B, Wang T, Wang H. LncRNA MALAT1 overexpression is an unfavorable prognostic factor in human cancer: evidence from a meta-analysis. International Journal of Clinical and Experimental Medicine. 2015; 8: 5499-5505.

3. Yuan Z, Li J, Hu R, Jiao Y, Han Y, Weng Q. Predictive assessment in pharmacogenetics of XRCC1 gene on clinical outcomes of advanced lung cancer patients treated with platinum-based chemotherapy. Scientific reports. 2015; 5: 16482.

4. Cui Z, Yin Z, Li X, Wu W, Guan P, Zhou B. Association between polymorphisms in XRCC1 gene and clinical outcomes of patients with lung cancer: a meta-analysis. BMC Cancer. 2012; 12: 71.

5. Du H, Zhang X, Du M, Guo N, Chen Z, Shu Y, Zhang Z, Wang M, Zhu L. Association study between XPG Asp1104His polymorphism and colorectal cancer risk in a Chinese population. Scientific reports. 2014; 4: 6700.

6. Bernig T, Chanock SJ. Challenges of SNP genotyping and genetic variation: its future role in diagnosis and treatment of cancer. Expert Review of Molecular Diagnostics. 2006; 6: 319-331.

7. Wood RD, Mitchell M, Sgouros J, Lindahl T. Human DNA repair genes. Science. 2001; 291: 1284-1289.

8. Wang F, Zhang SD, Xu HM, Zhu JH, Hua RX, Xue WQ, Li XZ, Wang TM, He J, Jia WH. XPG rs2296147 T>C polymorphism predicted clinical outcome in colorectal cancer. Oncotarget. 2016; 7:11724-11732. doi: 10.18632/ oncotarget. 7352 .

9. Chen JF, Liang HJ, Zou L, Jiang JY, Chen KL, Wang D, Liao L. Relationship between ERCC5 $+25 \mathrm{~A}>\mathrm{G}$ polymorphism and clinical outcome of patients with advanced colorectal cancer treated with platinumbased chemotherapy. Chinese Clinical Oncology. 2011; 16: 9-13.

10. Chen J, Xie F, Chen K, Wang D, Jiang H, Li J, Pan F, Chen S, Zhang Y, Ruan Z, Huang H, Zou L, Liang H. ERCC5 promoter polymorphisms at -763 and +25 predict the response to oxaliplatin-based chemotherapy in patients with advanced colorectal cancer. Cancer biology \& therapy. 2009; 8: 1424-1430. 
11. Chen JF. Detection and functional analysis of SNPs in the ERCC5 promoter in patients with advanced colorectal cancer treated with platinum-based chemotherapy. Third Military Medical University of Chinese P.L.A. 2009; Doctoral thesis.

12. Hu P, Kang S, Zhou RM, Wang N, Qi BL, Li Y. The association between the polymorphisms of XPG tagSNPs and the clinical outcomes of epithelial ovarian cancer patients treated with platinum-based chemotherapy. Chinese Journal of Practical Gynecology and Obstetrics. 2015; 31: 230-234.

13. Hu P. The associated between the polymorphisms of XPG gene and the clinical outcome of epithelial ovarian cancer patients with platinum-based chemotherapy. Hebei Medical University. 2014; Master thesis.

14. Wyss AB, Weissler MC, Avery CL, Herring AH, Bensen JT, Barnholtz-Sloan JS, Funkhouser WK, Olshan AF. Single nucleotide polymorphisms in nucleotide excision repair genes, cancer treatment, and head and neck cancer survival. Cancer causes \& control: CCC. 2014; 25: 437-450.

15. Zou HZ, Zhao YQ. XPG polymorphisms are associated with prognosis of advanced non-small cell lung cancer treated with platinum-based doublet chemotherapy. Genetics and molecular research: GMR. 2015; 14: 500-506.

16. Hu W, Pan J, Zhao P, Yang G, Yang S. Genetic polymorphisms in XPG could predict clinical outcome of platinum-based chemotherapy for advanced non-small cell lung cancer. Tumour biology: the journal of the International Society for Oncodevelopmental Biology and Medicine. 2014; 35: 5561-5567.

17. He C, Duan Z, Li P, Xu Q, Yuan Y. Role of ERCC5 promoter polymorphisms in response to platinum-based chemotherapy in patients with advanced non-small-cell lung cancer. Anti-Cancer Drugs. 2013; 24: 300-305.

18. Zhang T, Sun J, Lv M, Zhang L, Wang X, Ren JC, Wang B. XPG is predictive gene of clinical outcome in advanced non-small-cell lung cancer with platinum drug therapy. Asian Pacific journal of cancer prevention: APJCP. 2013; 14: 701-705.

19. Yi Y, Sun Z, Wang X, Li S, Wu Z, Zhu Y-H, Sun B, Cui $\mathrm{J}-\mathrm{W}$. XPG is a novel biomarker of clinical outcome in advanced non-small-cell lung cancer. Pakistan Journal of Medical Sciences. 2013; 29: 762-767.

20. Deng N. Correlation between polymorphisms of ERCC5 and risk of gastric cancer and prognosis and the effect on expression of ERCC5 encoding protein XPG. Chinese Medical University. 2014; Doctoral thesis.

21. Zhao YL, Yang LB, Geng XL, Zhou QL, Qin H, Yang L, Dong YZ, Zhong JJ. The association of XPG and MMS19L polymorphisms response to chemotherapy in osteosarcoma. Pakistan Journal of Medical Sciences. 2013; 29: 1225-1229.

22. Bai SB, Chen HX, Bao YX, Luo X, Zhong JJ. Predictive impact of common variations in DNA repair genes on clinical outcome of osteosarcoma. Asian Pacific journal of cancer prevention: APJCP. 2013; 14: 3677-3680.
23. Zhu ML, Wang M, Cao ZG, He J, Shi TY, Xia KQ, Qiu LX, Wei QY. Association between the ERCC5 Asp1104His polymorphism and cancer risk: a meta-analysis. PLoS One. 2012; 7: e36293.

24. Na N, Dun E, Ren L, Li G. Association between ERCC5 gene polymorphisms and breast cancer risk. International Journal of Clinical and Experimental Pathology. 2015; 8: 3192-3197.

25. Xue MH, Li GY, Wu XJ, Zhang CX, Zhang CF, Zhu KX. Genetic variability of genes in NER pathway influences the treatment outcome of gastric cancer. International Journal of Clinical and Experimental Pathology. 2015; 8: 5563-5569.

26. Paszkowska-Szczur K, Scott RJ, Gorski B, Cybulski C, Kurzawski G, Dymerska D, Gupta S, van de Wetering T, Masojc B, Kashyap A, Gapska P, Gromowski T, Kladny J, Lubinski J, Debniak T. Polymorphisms in nucleotide excision repair genes and susceptibility to colorectal cancer in the Polish population. Molecular Biology Reports. 2015; 42: 755-764.

27. He XF, Liu LR, Wei W, Liu Y, Su J, Wang SL, Shen XL, Yang XB. Association between the XPG Asp1104His and XPF Arg415Gln polymorphisms and risk of cancer: a metaanalysis. PLoS One. 2014; 9: e88490.

28. Mirecka A, Paszkowska-Szczur K, Scott RJ, Gorski B, van de Wetering T, Wokolorczyk D, Gromowski T, SerranoFernandez P, Cybulski C, Kashyap A, Gupta S, Golab A, Slojewski M, Sikorski A, Lubinski J, Debniak T. Common variants of xeroderma pigmentosum genes and prostate cancer risk. Gene. 2014; 546: 156-161.

29. Lu B, Li J, Gao Q, Yu W, Yang Q, Li X. Laryngeal cancer risk and common single nucleotide polymorphisms in nucleotide excision repair pathway genes ERCC1, ERCC2, ERCC3, ERCC4, ERCC5 and XPA. Gene. 2014; 542: 64-68.

30. Moher D, Liberati A, Tetzlaff J, Altman DG. Preferred reporting items for systematic reviews and meta-analyses: the PRISMA statement. Plos Medicine. 2009; 6: e1000097.

31. Cochran WG. The combination of estimates from different experiments. Biometrics. 1954; 10: 101-129.

32. Higgins JP, Thompson SG. Quantifying heterogeneity in a meta-analysis. Statistics in Medicine. 2002; 21: 1539-1558.

33. Higgins JP, Thompson SG, Deeks JJ, Altman DG. Measuring inconsistency in meta-analyses. BMJ. 2003; 327: 557-560.

34. Lau J, Ioannidis JP, Schmid CH. Quantitative synthesis in systematic reviews. Annals of Internal Medicine. 1997; 127: 820-826.

35. Mantel N, Haenszel W. Statistical aspects of the analysis of data from retrospective studies of disease. JNCI-Journal of the National Cancer Institute. 1959; 22: 719-748.

36. DerSimonian R, Laird N. Meta-analysis in clinical trials. Controlled Clinical Trials. 1986; 7: 177-188.

37. Begg CB, Mazumdar M. Operating characteristics of a rank correlation test for publication bias. Biometrics. 1994; 50: 1088-1101. 